\title{
Next Generation Sequencing Technologies: A Short Review
}

Tarek Hamed Attia ${ }^{1^{*}}$ and Maysaa Abdallah Saeed ${ }^{2}$

${ }^{1}$ Pediatric Department, Faculty of Medicine, Zagazig University, Egypt

${ }^{2}$ Tropical Medicine Department, Faculty of Medicine, Zagazig University, Egypt

"Corresponding author: Tarek Hamed Attia, Professor of Pediatrics, Zagazig University, Zagazig, Zagazig University, Faculty of Medicine, Pediatric Department, Egypt, Tel: 00201276099800; E-mail: tareqhamed@live.com

Rec date: Jan 25, 2016; Acc date: Feb 9, 2016; Pub date: Feb 12, 2016

Copyright: (c) 2016 Attia TH, et al. This is an open-access article distributed under the terms of the Creative Commons Attribution License, which permits unrestricted use, distribution, and reproduction in any medium, provided the original author and source are credited.

\begin{abstract}
When the editorial board invited me to write this short review, I remembered my old dream since thirty years ago, is it possible for mankind to live without more health burden? Scientists can answer a lot of difficult questions like this one. The science is growing very fast and next generation sequencing technologies are currently the hottest topic in the field of human and animal genomics researches. In this mini review, I have highlighted some basic knowledge about next generation sequencing technologies and its value for human health.
\end{abstract}

Keywords: Sequencing technologies; Exome; Genomic captures; Mitochondria

\section{Introduction}

The science is growing very fast and next generation sequencing technologies are currently the hottest topic in the field of human and animal's enomgics researches [1]. Early efforts at sequencing genes were painstaking, time consuming, and labor intensive. This situation began to change during the mid-1970s, when researcher Frederick Sanger developed several faster, more efficient techniques to sequence DNA. Indeed, Sanger's work in this area was so ground breaking that it led to his receipt of the Nobel Prize in Chemistry in 1980 [2].

Next-generation sequencing (NGS) is a type of DNA sequencing technology that uses parallel sequencing of multiple small fragments of DNA to determine sequence [3]. In contrast to Sanger sequencing, the speed of sequencing and amounts of DNA sequence data generated with NGS, which is considered a "high-throughput technology", are exponentially greater, and are produced at significantly reduced costs [4]. Third-generation sequencing uses parallel sequencing similar to NGS, but unlike NGS, third-generation sequencing uses single DNA molecules rather than amplified DNA as a template. Thus, thirdgeneration sequencing potentially eliminates errors in DNA sequence introduced in the laboratory during the DNA amplification process $[5,6]$.

The starting material that provides a template for clinical NGS is double-stranded nuclear DNA. This can be obtained from a variety of cell types. In some cases, the DNA is further modified in the laboratory to remove non-coding regions when exome sequencing is performed $[7,8]$.

NGS can be used to sequence every nucleotide in an individual's DNA, or limited to smaller portions of the genome such as the exome or a preselected subset of genes $[9,10]$. Many second generation HTNGS platforms, are commercially available and the race for more additional platforms are continuously on the horizon [1]. The interpretation of the result of clinical NGS laboratories will reported as pathogenic, likely pathogenic, likely benign, benign and of unknown clinical significance [11]. The clinician and patient must be aware that the likelihood of receiving a result of "uncertain significance" is reasonably high, because the clinical implications of many variants are unknown [12].

As defined by the National Society of Genetic Counsellors, genetic counselling is the process of helping people understand and adapt to the medical, psychological and familial implications of genetic contributions to disease. This process helps to understand chance of disease occurrence or recurrence and provide platform for education about inheritance [13]. Consideration of NGS as a clinical tool for genetic diagnosis is appropriate in individuals for whom sequencing of a single gene is unlikely to provide a diagnosis especially in diseases with genetic heterogeneity $[14,15]$

NGS opens the entire spectrum of genomic alterations for the genetic analysis of complex traits. The main challenge in the fast growing HT-NGS technologies, is to cope with the analysis of vast production of sequencing database through advanced bioinformatics tools $[1,16]$.

\section{And Now, What is the Future NGS Technologies?}

In the near future, HT-NGS technologies with ultra-deep sequencing of genomic DNA will be very helpful for medical purpose like analysis of the disease etiology and development in new drugs $[1,17,18]$. These researches will be of great value for genetic improvement of animal health and productivity [19].

HT-NGS technologies is a promising tool in the analysis of chromatin immunoprecipitation coupled to DNA microarray (ChIPchip) or sequencing (ChIP-seq), RNA sequencing (RNA-seq), whole genome genotyping, de novo assembling and re-assembling of genome, genome wide structural variation, mutation detection and carrier screening, detection of inherited disorders and complex human diseases, DNA library preparation, paired ends and genomic captures, sequencing of mitochondrial genome and personal genomics [1].

At the end, in the future we have a lot of hopes and a lot of questions. 
Citation: Attia TH, Saeed MA (2016) Next Generation Sequencing Technologies: A Short Review. Next Generat Sequenc \& Applic S1: 006. doi:

Page 2 of 2

Do we have the ability to control the pathophysiology of the diseases by understanding in depth their genetic background?

Do we have the ability in the near future to control cancer and prevent its occurrence?

Do we have the capacity in the near future to prolong life expectancy of mankind and control aging?

Finally, I still have a dream, which is an old one, and the answer will come in the near future with the help of sequencing technologies.

\section{References}

1. Chandra SP, Rafal S, Andrzej T (2011) Sequencing technologies and genome sequencing. J Appl Genet 52: 413-435.

2. Adams J (2008) DNA sequencing technologies. Nature Education 1: 193.

3. Rizzo JM, Buck MJ (2012) Key principles and clinical applications of "next-generation" DNA sequencing. Cancer Prev Res (Phila) 5: 887-900.

4. Voelkerding KV, Dames SA, Durtschi JD (2009) Next-generation sequencing: from basic research to diagnostics. Clin Chem 55: 641-658.

5. Munroe DJ, Harris TJ (2010) Third-generation sequencing fireworks at Marco Island. Nature Biotechnology 28: 426-428.

6. Schadt EE, Turner S, Kasarskis A (2010) A window into third-generation sequencing. Hum Mol Genet 19: R227-R240.

7. Mardis ER (2008) The impact of next-generation sequencing technology on genetics. Trends Genet 3: 133-141.

8. Venter JC, Adams MD, Myers EW, Li PW, Mural RJ, et al. (2001) The sequence of the human genome. Science 291: 1304-1351.

9. Mardis ER (2008) Next-generation DNA sequencing methods. Annu Rev Genomics Hum Genet 9: 387-402.
10. Mardis ER (2011) A dacade’s perspective on DNA sequencing technology. Nature 470: 198-203.

11. Taylor JC, Martin HC, Lise S, Broxholme J, Cazier JB, et al. (2015) Factors influencing success of clinical genome sequencing across a broad spectrum of disorders. Nat Genet 47: 717-726.

12. Bamshad MJ, Ng SB, Bigham AW, Tabor HK, Emond MJ, et al. (2011) Exome sequencing as a tool for Mendelian disease gene discovery. Nat Rev Genet 12: 745-755.

13. National Society of Genetic Counselors Website.

14. Lee H, Deignan JL, Dorrani N, Strom SP, Kantarci S, et al. (2014) Clinical exome sequencing for genetic identification of rare Mendelian disorders. JAMA 312: 1880-1887.

15. Gilissen C, Hehir-Kwa JY, Thung DT, van de Vorst M, van Bon BW, et al. (2014) Genome sequencing identifies major causes of severe intellectual disability. Nature 511: 344-347.

16. Day-Williams AG, Zeggini E (2010) The effect of next-generation sequencing technology on complex trait research. Eur J Clin Invest 41: 561-567.

17. Meyerson M, Gabriel S, Getz G (2010) Advances in understanding cancer genomes through second-generation sequencing. Nat Rev Genet 11: 685-696.

18. Bowne SJ, Sullivan LS, Koboldt DC, Ding L, Fulton R, et al. (2011) Identification of disease-causing mutations in autosomal dominant retinitis pigmentosa (adRP) using next-generation DNA sequencing. Invest Ophthalmol Vis Sci 52: 494-503.

19. Green RD, Qureshi MA, Long JA, Burfening PJ, Hamernik DL (2007) Identifying the Future Needs for Long-Term USDA Efforts in Agricultural Animal Genomics. Int J Biol Sci 3: 185-191. 